Abstracta Iranica Iranica

Revue bibliographique pour le domaine irano-aryen

Volume 24 | 2003

Comptes rendus des publications de 2001

\title{
Iranian Cities, formation and development. Austin, Texas Univ. Press, 2001, 132 p.
}

\section{Bernard Hourcade}

\section{Q OpenEdition}

1 Journals

Édition électronique

URL : http://journals.openedition.org/abstractairanica/34952

DOI : 10.4000/abstractairanica.34952

ISSN : 1961-960X

\section{Éditeur :}

CNRS (UMR 7528 Mondes iraniens et indiens), Éditions de l'IFRI

\section{Édition imprimée}

Date de publication : 15 mai 2003

ISSN : 0240-8910

\section{Référence électronique}

Bernard Hourcade, «Iranian Cities, formation and development. Austin, Texas Univ. Press, 2001, 132 p. », Abstracta Iranica [En ligne], Volume 24 | 2003, document 348, mis en ligne le 05 janvier 2010, consulté le 25 septembre 2020. URL : http://journals.openedition.org/abstractairanica/34952 ; DOI : https:// doi.org/10.4000/abstractairanica.34952

Ce document a été généré automatiquement le 25 septembre 2020.

Tous droits réservés 


\title{
Iranian Cities, formation and development. Austin, Texas Univ. Press, 2001, $132 \mathrm{p}$.
}

\author{
Bernard Hourcade
}

1 Ce livre est important car il tente en peu de pages très bien documentées et illustrées, de montrer les caractères et l'originalité des villes iraniennes dans leur développement spatial, urbanistique et non pas du point de vue socio-politique ou économique. Ce travail de géographie historique montre donc comment les données naturelles, historiques, économiques et religieuses, ont un impact sur le tissu urbain et les structures de la ville; chacune des composantes de la ville iranienne est ainsi présentée, notamment à partir de l'exemple de Sabzevār. On regrettera que ce livre, qui est appelé à devenir un manuel de référence en la matière, soit trop descriptif et présente tous les aspects de l'urbanisme et de l'architecture sans toujours montrer la relation avec la caractère "iranien", islamique ou simplement local de ce qui est décrit. Mais peut être n'y a-t-il pas de réponse en l'état actuel des connaissances. Il est ainsi regrettable que les données sur le bazar, la mosquée ou les qanāt soient brièvement placés en annexe.

\section{INDEX}

Thèmes : 15.1. Iran 


\section{AUTEURS}

BERNARD HOURCADE

CNRS - Paris 